\title{
Faktor-Faktor yang Berhubungan dengan Pemanfaatan Pelayanan Posyandu Lansia
}

\section{The Associated Factors With Utilization Of Elderly Integrated Health Post}

\section{Nurvi Susanti* Mitra**}

*Prodi Pascasarjana IKM STIKes Hang Tuah Pekanbaru

\begin{abstract}
Abstrak
Laporan Dinas Kesehatan Kota Pekanbaru Tahun 2011 menunjukkan bahwa dari 19 Puskesmas yang ada di Pekanbaru, jumlah lansia terbanyak berada di wilayah kerja Puskesmas Garuda Pekanbaru (7360 orang), sedangkan jumlah kunjungan lansia (cakupan) hanya 14\% dari total lansia yang ada. Cakupan ini masih jauh dari target yang diharapkan yaitu $70 \%$. Tujuan penelitian adalah untuk mengetahui faktor-faktor yang berhubungan dengan pemanfaatan pelayanaan posyandu lansia. Desain penelitian adalah cross sectional study dengan sampel sebanyak 199 orang lansia. Cara pengambilan sampel adalah Systematic Random Sampling. Analisis bivariat menggunakan uji chi square, dan analisis multivariat menggunakan uji regresi logistik ganda. Hasil penelitian menunjukan bahwa variabel yang berhubungan signifikan dengan pemanfaatan pelayanaan posyandu lansia adalah sikap (POR: 6,08 95\%CI:1,57-23,51), jarak (POR:0,26 95\%CI:0,12-0,56), kader (POR:5,06 95\%CI: 2,36-10,86), dan pendidikan (POR:2,52 95\%CI:1,24-5,14). Variabel dukungan keluarga merupakan variabel konfounding (POR:2,00 95\%CI:0,87-4,59). Disarankan pada instansi terkait perlunya dilakukan upaya untuk meningkatkan pemanfaatan pelayanan posyandu lansia melalui promosi dan penyuluhan tentang pemanfaatan posyandu lansia serta meningkatkan pelayanan di posyandu sehingga lansia termotivasi untuk mengunjungi posyandu lansia.
\end{abstract}

Kata Kunci : Pemanfaatan Pelayanan Posyandu, Lansia

\begin{abstract}
Based on Pekanbaru City Health Office report in 2011 was obtained from 19 clinic centers in Pekanbaru city, clinic center Garuda Work Area has the largest number of elderly as many as 7360 people, while the number of visits elderly (scope) only $14 \%$ of the total elderly there. This coverage is still far from the expected target of $70 \%$. The research objective is to knowing the factors associated with utilization of the elderly in servicing clinic center Garuda Pekanbaru Work Area. Research design to types used are cross-section of Analytical Studies (cross sectional analytic study) a sample of 199 people. The sampling process is done by Systematic Random Sampling. Research results showed that there are variables related significantly between elderly utilization posyandu to research Attitudes, Distance, frame work, and Education. While family support is a variable Confonding. Relevant agencies are advised on the need for efforts to increase utilization of services through the promotion and the elderly posyandu counseling on the use of posyandu elderly and improve services in posyandu so motivated to visit clinic center elderly.
\end{abstract}

Keywords: Utilization Integrated Health Post, Elderly

\section{Pendahuluan}

Lanjut usia adalah penduduk yang telah mencapai usia 60 tahun ke atas. Di seluruh dunia jumlah penduduk lansia yang berusia 60 tahun keatas tumbuh dengan sangat cepat bahkan tercepat dibandingkan dengan usia lainnya. Menurut WHO 1995, Usia Harapan Hidup (UHH) tertinggi terdapat di Negara Jepang yaitu pria 76 tahun dan wanita 82 tahun. Sedangkan pada negara lainnya, pertumbuhan lansia

yang cepat di Amerika terjadi tahun 1990 menunjukan suatu kombinasi yang kuat antara penurunan angka kelahiran dan peningkatan usia hidup. Persentase warga Amerika yang berusia 65 tahun ke atas telah meningkat 3 kali lipat (4,1 \% pada tahun 1900 sampai 12,8\% pada tahun 1996) dan jumlahnya telah meningkat hampir 11 kali lipat (dari 31 juta sampai 33,9 juta), (Anderson, 2007). 
Diperkirakan mulai tahun 2010 akan terjadi ledakan jumlah penduduk lanjut usia. Laporan BPS (2010) menunjukkan bahwa persentase penduduk lanjut usia di Indonesia pada tahun 1990 adalah 6,29 \%, tahun 2000 sampai 2010 terjadi peningkatan dari 7,18\% menjadi 9,77\%. Diperkirakan pada tahun 2020 persentase penduduk lansia mencapai $11,34 \%$ dari keseluruhan jumlah penduduk (BPS,2010).

Salah satu hasil pembangunan kesehatan di Indonesia adalah meningkatnya UHH tahun 1990 pada perempuan 64,7 tahun dan laki-laki 62,9 tahun. (Dep Kes RI, 2005). Dilihat dari sisi ini pembangunan kesehatan di Indonesia sudah cukup berhasil, karena angka harapan hidup bangsa kita telah meningkat secara bermakna. Namun disisi lain dengan meningkatnya angka harapan hidup ini membawa beban bagi masyarakat, karena populasi penduduk usia lanjut meningkat dan bertambah cenderung lebih cepat (Nugroho, 2006).

Berdasarkan data yang diperoleh dari Dinas Kesehatan Provinsi Riau, jumlah lansia mengalami peningkatan dari 26.070 orang tahun 2007 tahun 2008 menjadi 23.288 orang dan 38.908 tahun 2009 (Profil Dinkes Provinsi Riau, 2010). Hasil studi tentang kondisi sosial ekonomi dan kesehatan lanjut usia yang dilakukan Komnas Lansia, diketahui bahwa penyakit kronis terbanyak yang diderita lansia adalah penyakit sendi $(52,3 \%)$, hipertensi $(38,8 \%)$ dan katarak $(23 \%)$. Penyakit-penyakit tersebut merupakan penyakit utama pada lansia (Depkes RI, 2008). Di Indonesia kurang lebih sekitar $70 \%$ lanjut usia menderita penyakit kronis (Purnomo, 2010).

Posyandu Lansia merupakan wahana pelayanan bagi kaum usia lanjut, yang dilakukan dari, oleh, dan untuk kaum usila yang menitik beratkan pada pelayanan promotif dan preventif, tanpa mengabaikan upaya kuratif dan rehabilitatif. Apapun upaya promotif dan preventif tersebut dapat diterapkan dengan melaksanakan kegiatan posyandu Lansia dan menerapkan pola hidup sehat serta berperan aktif dalam gerakan kesehatan di usia lanjut dengan tujuan untuk mewujudkan masa tua yang berbahagia dan berguna (Martono, 2001).

Berdasarkan laporan Dinas Kesehatan Kota Pekanbaru Tahun 2010 diperoleh bahwa dari 19 puskesmas yang ada di kota Pekanbaru, wilayah kerja puskesmas Garuda yang memiliki lansia terbanyak yaitu 7362 orang, yang terdiri dari empat Kelurahan yaitu Kelurahan Tangkerang Barat, Tangkerang Tengah, Sidomulyo Timur dan Wonorejo. Sedangkan jumlah posyandu lansia yang ada di Wilayah Kerja Puskesmas Garuda sebanyak 7 posyandu, dengan jumlah kunjungan 1042 orang. Adapun cakupan pada tahun 2010 dengan jumlah cakupan $14 \%$. Jumlah cakupan ini masih dibawah target yang diharapkan yaitu $70 \%$.

Berdasarkan uraian diatas dapat dilihat masih banyak usia lanjut yang belum mengikuti kegiatan posyandu lansia. Berdasarkan undang-undang No.36 tahun 2009 tentang kesehatan pasal 138 yang menyatakan bahwa pemerintah wajib menjamin ketersediaan fasilitas pelayanan kesehatan dan memfasilitasi kelompok lanjut usia untuk dapat tetap hidup mandiri dan produktif. Berdasarkan Hal diatas program posyandu lansia sangat bermanfaat sekali bagi usia lanjut. Dari uraian diatas maka peneliti tertarik untuk meneliti masalah faktor yang mempengaruhi pemanfaatan pelayanan posyandu lanjut usia di wilayah kerja Puskesmas Garuda Kota Pekanbaru Tahun 2011. Tujuan penelitian untuk mengetahui hubungan pengetahuan, sikap, jarak, dukungan keluarga, petugas kesehatan, jumlah kader, umur lansia, jenis kelamin lansia, status perkawinan, pendidikan dan pekerjaan dengan pemanfaatan pelayanan posyandu lansia di wilayah kerja Puskesmas Garuda Kota Pekanbaru Tahun 2011.

\section{Metode}

Penelitian ini merupakan penelitian kuantitatif analitik dengan disain cross sectional study. Lokasi penelitian di wilayah kerja Puskesmas Garuda Kota Pekanbaru. Populasi adalah lansia dengan usia 45 tahun s/d 70 tahun keatas, sebanyak 7362 orang. Besar sampel di tentukan dengan menggunakan rumus sampel size for one sampel test of proportian (level of singnificance 5\%, power $90 \%$, alternative hypothesis I sided), diperoleh 199 orang lansia. Tekhnik pengambilan sampel dengan cara sistematik random sampling. Data dikumpulkan dengan wawancara dan menyebar kuesioner pada lansia. Analisis data dilakukan secara univariat, bivariat dengan menggunakan uji chi square dan multivariat dengan uji regresi logistik ganda.

\section{Hasil \\ Analisis Univariat}

Hasil analisis univariat menunjukkan bahwa sebagian besar lansia $(62,8 \%)$ tidak memanfaatkan pelayanan posyandu lansia. Berdasarkan karakteristik lansia ditemui bahwa sebagian besar lansia $(60,8 \%)$ berjenis kelamin perempuan, hampir sebagian lansia berpendidikan tinggi $(45,7 \%)$, umumnya lansia berstatus kawin $(72,9 \%)$, lansia terbanyak berada pada kelompok umur $45-54$ tahun $(66,8 \%)$ dan kebanyakan lansia tidak berkerja $(61,3 \%)$. Sebagian besar lansia mempunyai 
persepsi bahwa petugas kesehatan yang memberikan pelayanan di posyandu lansia adalah baik $(76,9 \%)$. Lebih dari sebagian lansia berpengetahuan rendah $(52,3 \%)$, jarak tempuh yang jauh (59,3\%), dan mendapatkan motivasi dari kader $(50,8 \%)$. Hanya sebagian kecil saja lansia yang mempunyai sikap negatif $(19,1 \%)$

Tabel 1

Hasil Analisis Univariat

\begin{tabular}{|c|c|c|}
\hline Variabel & Frekuensi & Persentase $(\%)$ \\
\hline \multicolumn{3}{|l|}{ Pemanfaatan Posyandu Lansia } \\
\hline 1. Tidak memanfaatkan & 125 & 62,8 \\
\hline 2. Memanfaatkan & 74 & 37,2 \\
\hline \multicolumn{3}{|l|}{ Pengetahuaan } \\
\hline 1. Rendah & 104 & 52,3 \\
\hline 2. Tinggi & 95 & 47,7 \\
\hline \multicolumn{3}{|l|}{ Sikap } \\
\hline 1. Negatif & 38 & 19,1 \\
\hline 2. Positif & 161 & 80,9 \\
\hline \multicolumn{3}{|l|}{ Jarak Tempuh } \\
\hline 1. Jauh & 118 & 59,3 \\
\hline 2. Dekat & 81 & 40,7 \\
\hline \multicolumn{3}{|l|}{ Dukungan Keluarga } \\
\hline 1. Tidak ada & 74 & 37,2 \\
\hline 2. Ada & 125 & 62,8 \\
\hline \multicolumn{3}{|l|}{ Petugas Kesehatan } \\
\hline 1. Tidak baik & 46 & 23,1 \\
\hline 2. Baik & 153 & 76,9 \\
\hline \multicolumn{3}{|l|}{ Kader } \\
\hline 1. Tidak ada & 98 & 49,2 \\
\hline 2. Ada & 101 & 50,8 \\
\hline \multicolumn{3}{|l|}{ Umur } \\
\hline 1. $45-54$ & 133 & 66,8 \\
\hline 2. 55 tahun keatas & 66 & 33,2 \\
\hline \multicolumn{3}{|l|}{ Jenis kelamin } \\
\hline 1. Laki-laki & 78 & 39,2 \\
\hline 2. Perempuan & 121 & 60,8 \\
\hline \multicolumn{3}{|l|}{ Status Perkawinaan } \\
\hline 1. Tidak kawin & 54 & 27,1 \\
\hline 2. Kawin & 145 & 72,9 \\
\hline \multicolumn{3}{|l|}{ Pendidikan } \\
\hline 1. Rendah & 108 & 54,3 \\
\hline 2. Tinggih & 91 & 45,7 \\
\hline \multicolumn{3}{|l|}{ Pekerjaan } \\
\hline 1. Tidak berkerja & 122 & 61,3 \\
\hline 2. Berkerja & 77 & 38,7 \\
\hline Total & 199 & 100 \\
\hline
\end{tabular}

\section{Analisis Bivariat}

Analisis bivariat dengan uji Chi Square menunjukkan bahwa variabel yang berhubungan dengan pemanfaatan pelayanan posyandu lansia adalah variabel pengetahuan (POR 1,95 95\% CI: 1,09-3,49), sikap
(POR 9,20 95\% CI:2,72-31,15), jarak tempuh (POR 0,47 95\% CI:0,26-0,87), dukungan keluarga (OR 3,95 95\% CI:2,01-7,80), motivasi kader (POR 6,91 95\% CI:3,5513,44) dan pendidikan (POR 2,66 95\% CI:1,48-4,82). 
Tabel 2

Hasil Analisis Bivariat

\begin{tabular}{|c|c|c|c|c|c|}
\hline \multirow[t]{3}{*}{ Variabel } & \multicolumn{2}{|c|}{ Pemanfaatan Pelayanan Posyandu Lansia } & \multirow[t]{2}{*}{ Total } & \multirow[t]{3}{*}{$\mathrm{P}$ value } & \multirow{3}{*}{$\begin{array}{c}\text { OR } \\
(95 \% \mathrm{CI})\end{array}$} \\
\hline & Tidak memanfaatkan & Memanfaatkan & & & \\
\hline & $\mathrm{n}(\%)$ & $\mathrm{n}(\%)$ & $\mathrm{n}(\%)$ & & \\
\hline \multicolumn{6}{|l|}{ Pengetahuaan } \\
\hline Rendah & $73(70,2)$ & $31(29,8)$ & $104(100,0)$ & & \\
\hline Tinggih & $52(54,7)$ & $43(45,3)$ & $95(100,0)$ & 0,035 & $1,947(1,087-3,488)$ \\
\hline Jumlah & $125(62,8)$ & $74(37,2)$ & $199(100,0)$ & & \\
\hline \multicolumn{6}{|l|}{ Sikap } \\
\hline Negatif & $35(92,1)$ & $3(7,9)$ & $38(100,0)$ & & \\
\hline Positif & $90(55,9)$ & $71(44,1)$ & $161(100,0)$ & 0,000 & $9,204(2,719-31,15)$ \\
\hline Jumlah & $125(62,8)$ & $74(37,2)$ & $199(100,0)$ & & \\
\hline \multicolumn{6}{|l|}{ Jarak Tempuh } \\
\hline Jauh & $66(55,9)$ & $52(44,1)$ & $118(100,0)$ & & \\
\hline Dekat & $59(72,8)$ & $22(27,2)$ & $81(100,0)$ & 0,023 & $0,473(0,257-0,871)$ \\
\hline Jumlah & $125(62,8)$ & $74(37,2)$ & 199(100,0) & & \\
\hline \multicolumn{6}{|c|}{ Dukungan Keluarga } \\
\hline Tidak ada & $60(81,1)$ & $14(18,9)$ & $74(100,0)$ & & \\
\hline Ada & $65(52,0)$ & $60(48,0)$ & $125(100,0)$ & 0,000 & $3,956(2,005-7,804)$ \\
\hline Jumlah & $125(62,8)$ & $74(37,2)$ & 199(100,0) & & \\
\hline \multicolumn{6}{|c|}{ Petugas Kesehatan } \\
\hline Tidak baik & $33(71,7)$ & $13(28,3)$ & $46(100,0)$ & & \\
\hline Baik & $92(60,1)$ & $61(39,9)$ & $153(100,0)$ & 0,210 & $1,683(0,280-3,454)$ \\
\hline Jumlah & $125(62,8)$ & $74(37,2)$ & 199(100,0) & & \\
\hline \multicolumn{6}{|l|}{ Motivasi Kader } \\
\hline Tidak ada & $82(83,7)$ & $16(16,3)$ & $98(100,0)$ & & \\
\hline Ada & $43(42,6)$ & $58(57,4)$ & $101(100,0)$ & 0,000 & $6,913(3,554-13,44)$ \\
\hline Jumlah & $125(62,8)$ & $74(37,2)$ & 199(100,0) & & \\
\hline \multicolumn{6}{|l|}{ Umur } \\
\hline $45-54$ & $85(63,9)$ & $48(36,1)$ & $133(100,0)$ & & \\
\hline 55tahun keatas & $40(60,6)$ & $26(39,4)$ & $66(100,0)$ & 0,766 & $1,151(0,627-2,113)$ \\
\hline Jumlah & $125(62,8)$ & $74(37,2)$ & 199(100,0) & & \\
\hline \multicolumn{6}{|l|}{ Jenis kelamin } \\
\hline Laki-laki & $49(62,8)$ & $29(100,0)$ & $78(100,0)$ & & \\
\hline Perempuan & $76(62,8)$ & $121(100,0)$ & $121(100,0)$ & 1,000 & $1,000(0,555-1,803)$ \\
\hline Jumlah & $125(62,8)$ & $199(100,0)$ & 199(100,0) & & \\
\hline \multicolumn{6}{|c|}{ Status Perkawinaan } \\
\hline Tidak kawin & $40(74,1)$ & $14(25,9)$ & $54(100,0)$ & & \\
\hline Kawin & $85(58,6)$ & $60(41,4)$ & $145(100,0)$ & 0,066 & $2,017(1,009-4,031)$ \\
\hline Jumlah & $125(62,8)$ & $74(37,2)$ & 199(100,0) & & \\
\hline \multicolumn{6}{|l|}{ Pendidikan } \\
\hline Rendah & $79(73,1)$ & $29(26,9)$ & $108(100,0)$ & & \\
\hline Tinggih & $46(50,5)$ & $45(49,5)$ & $91(100,0)$ & 0,002 & $2,665(1,475-4,815)$ \\
\hline Jumlah & $125(62,8)$ & $74(37,2)$ & $199(100,0)$ & & \\
\hline \multicolumn{6}{|l|}{ Pekerjaan } \\
\hline Tidak berkerja & $73(59,8)$ & $49(40,2)$ & $122(100,0)$ & & \\
\hline Berkerja & $52(67,5)$ & $25(32,5)$ & $77(100,0)$ & 0,345 & $0,716(0,394-1,304)$ \\
\hline Jumlah & $125(62,8)$ & $74(37,2)$ & $199(100,0)$ & & \\
\hline
\end{tabular}




\section{Analisis Multivariat}

Berdasarkan uji seleksi bivariat, terdapat 8 variabel yang dijadikan sebagai kandidat multivariat $(\mathrm{p}<0,25)$, yaitu variabel pengetahuan, sikap, jarak tempuh, dukungan keluarga, petugas kesehatan, motivasi kader, status perkawinan dan pendidikan.

Hasil akhir pemodelan multivariat, didapatkan 4 variabel yang berhubungan signifikan dengan pemanfaatan pelayanan posyandu lansia yaitu variabel sikap, jarak tempuh, motivasi kader dan pendidikan lansia. variabel dukungan keluarga merupakan variabel konfounding. Variabel yang paling dominan berhubungan dengan pemanfaatan pelayanan posyandu lansia adalah sikap lansia. Lansia yang bersikap negatif lebih beresiko 6 kali untuk tidak memanfaatkan pelayanan posyandu lansia dibandingkan dengan lansia yang bersikap positif setelah dikontrol oleh variabel sikap, jarak tempuh, dukungan keluarga, motivasi kader dan pendidikan.

Tabel 3

Pemodelan Multivariat (Akhir)

\begin{tabular}{lcccc}
\hline \multicolumn{1}{c}{ Variabel } & P & Exp & \multicolumn{2}{c}{$95 \%$ CI for Exp } \\
& Value & (B) & \multicolumn{2}{c}{ (B) } \\
\cline { 4 - 5 } & & & Lower & Upper \\
\hline Sikap & 0,009 & 6,077 & 1,571 & 23,514 \\
Jarak Tempuh & 0,001 & 0,263 & 0,124 & 0,559 \\
Dukungan Keluarga & 0,100 & 2,006 & 0,876 & 4,593 \\
Motivasi Kader & 0,000 & 5,064 & 2,362 & 10,856 \\
Pendidikan & 0,011 & 2,523 & 1,239 & 5,141 \\
\hline
\end{tabular}

\section{Pembahasan}

Faktor-faktor yang berhubungan dengan Pemanfaatan Posyandu Lansia

\section{Sikap}

Lansia dengan sikap negatif yang lebih beresiko untuk tidak memanfaatkan pelayanan posyandu lansia dibandingkan dengan lansia yang mempunyai sikap positif. Lansia bersikap positif sudah memiliki pengetahuan, informasi, dan pendidikan. Menurut Green (1980) dalam Notoadmodjo (2003) menerangkan bahwa sikap dipengaruhi oleh faktor predisposisi yang mencakup pengetahuan dan sikap masyarakat tentang kesehatan, tradisi dan kepercayaan terhadap hal-hal yang berkaitan dengan kesehatan

Berdasarkan hasil yang didapatkan bahwa lansia yang sikap negatif yang tidak memanfaatkan pelayanan posyandu lansia untuk itu perlunya adanya dukungan dan motivasi dari tenaga kesehatan sehingga sikap lansia berubah menjadi positif.

\section{Jarak Tempuh}

Berdasarkan hipotesis bahwa proporsi lansia dengan jarak tempuh jauh lebih berisiko untuk tidak memanfaatkan pelayanan posyandu lansia bila dibandingkan dengan jarak tempuh dekat. Namun hasil penelitian tidak sesuai dengan hipotesis tersebut, justru lansia yang berjarak jauh lebih banyak memanfaatkan pelayanan posyandu lansia dan mereka berjarak dekat yang tidak memanfaatkan pelayanan posyandu lansia. Hal ini mungkin dikarenakan disekitar posyandu lansia ada banyak lansia dengan tingkat perekonomian yang lebih tinggi dan berobat ke rumah sakit. Sehingga tidak memanfaatkan posyandu lansia, namun perlu dilakukan penelitian lebih lanjut.

Penelitian menunjukkan hasil yang sama dengan penelitian Henniwati (2006) yang mengatakan bahwa ada hubungan yang signifikan antara jarak dari rumah kepelayanan kesehatan.

\section{Motivasi Kader}

Bila kader tidak memberikan informasi kepada lansia maka lansia tidak akan memanfaatkan pelayanan posyandu lansia. Kader selain mempunyai tugas dan fungsi juga harus mampu berkomunikasi dengan baik dan mampu mengajak dan memotivasi kelompok maupun masyarakat. Kader harus juga dapat membina semua yang terkait dengan pelaksanaan posyandu, tetapi memantau pertumbuhan perkembangan lansia (Depkes RI, 2005). Untuk meningkatkan citra diri kader maka harus diperhatikan dan meningkatkan kualitas diri sebagai kader. Selain itu diharapkan kader bersama keluarganya supaya memotivasi lansia memanfaatkan pelayanan posyandu lansia.

\section{Pendidikan}

Berdasarkan pendidikan responden dengan latar belakang pendidikan terbanyak tingkat dasar (SD-SMP) $73,1 \%$ dan yang paling sedikit tingkat (SMA/D3-SI) $50,5 \%$. Lansia berpendidikan rendah berisiko tidak memanfaatkan pelayanan posyandu dibandingkan berpendidikan tinggi. Hasil penelitian ini sejalan dengan penelitian Henniwati (2008) yang menyatakan ada hubungan pendidikan dengan pemanfaatan posyandu lansia.

Tingkat pendidikan secara langsung merupakan salah satu faktor yang ikut mempengaruhi seseorang untuk ikut serta dalam memanfaatkan pelayanan kesehatan. Tingkat pendidikan bisa mempermudah seseorang untuk melakukan suatu perilaku kesehatan. Seseorang yang berpendidikan tinggi akan mudah dalam menerima dan menyerap informasi baru sehingga 
pengetahuan menjadi lebih baik dalam pengambilan keputusan tentang pemanfaatan pelayanan posyandu.

Tingkat pendidikan lansia tidak bisa di intervensi langsung oleh sektor kesehatan, oleh sebab itu penekanan yang penting pada lansia yang berpendidikan dasar adalah pemberian informasi melalui penyuluhan sehingga dengan diberikan pengetahuan tentang pemanfaatan posyandu lansia, walaupun dengan pendidikan rendah akan membantu proporsi peningkatan pelayanan pemanfaatan posyandu lansia.

\section{Dukungan Keluarga}

Hasil uji statistik diperoleh nilai p: 0,10 (CI 95\% : 0,9-4,6) setelah dilakukan perubahan nilai OR maka didapatkan bahwa terdapat variabel $>$ dari $10 \%$. Maka variabel dukungan keluarga merupakan variabel yang konfounding.

Dukungan keluarga merupakan faktor yang sangat berperan dalam keluarga bisa menjadi motivator kuat bagi lansia apabila selalu menyediakan diri untuk mendampingi atau mengantar lansia ke posyandu, mengingatkan lansia jika lupa jadwal posyandu, dan berusaha membantu mengatasi segala permasalahan bersama lansia

\section{Faktor-faktor yang tidak berhubungan dengan Pemanfaatan Pelayanan Posyandu Lansia}

\section{Pengetahuaan}

Hasil analisis multivariat menunjukkan bahwa tidak ada hubungan yang signifikan pengetahuan dengan pemanfaatan pelayanaan posyandu lansia. Kemungkinan disebabkan oleh adanya bias informasi. Sebagian besar pengetahuan manusia diperoleh melalui mata dan telinga. Pengetahuan yang dicakup didalam kognitif mempunyai 6 tingkatan yaitu tahu, memahami, aplikasi, analisis, sintesis dan evaluasi. Apabila tingkat pengetahuan sudah mencapai tahap evaluasi maka seseorang telah memiliki kemampuan untuk melakukan justifikasi atau penilaian terhadap suatu materi atau objek (Notoatmodjo, 2003).

Mengingat kebutuhan pelayanan kesehatan merupakan masalah utama bagi para lansia, pemerintah bekerjasama dengan masyarakat telah berupaya menambah fasilitas kesehatan yaitu dengan dibukanya posyandu lansia. Pelaksanaan posyandu lansia diharapkan dapat menjalankan fungsinya sebagai unit terdepan dalam melakukan pembinaan dan pelayanan

kesehatan kepada lansia yang meliputi pemeriksaan kesehatan fisik dan mental emosional. Kartu Menuju Sehat (KMS) usia lanjut sebagai alat pencatat dan pemantau untuk mengetahui lebih awal penyakit yang diderita atau ancaman masalah kesehatan yang dihadapi dan mencatat perkembangannya dalam Buku Pedoman Pemeliharaan Kesehatan (BPPK) lansia atau catatan kondisi kesehatan. (Hermiyanti, 2005).

\section{Petugas Kesehatan}

Hasil uji statistik diperoleh nilai (CI 95\% : 0,3$2,0)$ maka dapat disimpulkan bahwa tidak ada hubungan yang signifikan antara petugas kesehatan dengan pemanfaatan pelayanaan posyandu lansia. Kemungkinan disebabkan oleh adanya bias informasi dalam penyusunan pertanyaan yang mungkin berbeda dengan penelitian terdahulu.

Persepsi lansia yang tidak baik terhadap petugas kesehatan berisiko lansia tidak memanfaatkan pelayanan posyandu lansia, tapi dalam penelitian ini tidak terbukti. Persepsi ini mungkin tentang posyandu berbeda dengan hasil penelitian yang dilakukan Diyana. Ediyana (2005) menyatakan bahwa peranan petugas kesehatan mempuyai hubungan kuat terhadap perilaku masyarakat dalam pemanfaatan pelayanan kesehatan. Kemaknaan data hasil penelitiaan pada variabel petugas kesehatan menunjukan peran petugas kesehatan dinyatakan oleh responden belum berperan dengan baik. Oleh karena itu belum terbentuknya perilaku responden yang baik dalam memanfaatkan pelayanaan kesehatan sangat diperlukan adanya petugas kesehatan secara terus menerus dan berkesinambungan dalam melakukan pendekatan dan memberikan informasi kesehatan kepada masyarakat. Hasil penelitiaan ini menunjukan hasil yang sama dengan Henniwati (2009) bahwa tidak ada hubungan antara petugas kesehatan dengan pemanfaatan pelayanaan posyandu lansia.

\section{Umur}

Hasil uji statistik diperoleh nilai (CI 95\% : 0,62,1) maka dapat disimpulkan bahwa tidak ada hubungan yang signifikan antara umur dengan pemanfaatan pelayanaan posyandu lansia. Ini dikarenakan sampel yang terlalu kecil. Hasil penelitian ini menunjukan hasil yang sama dengan Miller (1999) yang dikutip Hardywinoto (2007), menyatakan makin tua umur seseorang maka semakin banyak fungsi organ tubuh yang mengalami gangguan atau masalah yang berdampak pada kebutuhan klien akan pemeliharaan kesehatan

\section{Jenis kelamin}

Hasil uji statistik diperoleh nilai (CI 95\% : 0,61,8) maka dapat disimpulkan bahwa tidak ada hubungan 
yang signifikan Status perkawinan dengan pemanfaatan pelayanaan posyandu lansia. Ini disebabkan persentase tidak berbeda antara laki-laki dan perempuan dalam pemanfatan pelayaan posyandu lansia. Menurut penelitian yang dilakukan oleh Harianto (2004) menunjukan hasil yang sama bahwa tidak ada hubungan antara jenis kelamin dengan pemanfaatan pelayanan posyandu lansia.

\section{Status perkawinaan}

Hasil uji statistik diperoleh nilai (CI 95\% : 1,04,0) maka dapat disimpulkan bahwa tidak ada hubungan yang signifikan status perkawinan dengan pemanfaatan pelayanaan posyandu lansia. Ini kemungkinaan disebabkan adanya bias informasi.

\section{Pekerjaan}

Hasil uji statistik diperoleh nilai (CI 95\% : 0,41,4) maka dapat disimpulkan bahwa tidak ada hubungan yang signifikan pekerjaan dengan pemanfaatan pelayanaan posyandu lansia. Ini kemungkinaan disebabkan adanya bias informasi. Hal ini dikarenakan bahwa lansia yang datang ke posyandu rata-rata adalah pensiunan dan tidak mempunyai penghasilan tetap. Menurut Sakemas (1991), yang dikutip oleh Nurhayati (2007), lansia yang ada di perkotaan, Sebagian besar menerima gaji/upah yang rendah, dikarenakan tingkat pendidikan lansia yang masih sangat rendah. Menurut Sedarmayanti (2001) yang dikutip oleh Handywinoto (2007), pekerjaan yang disertai dengan pendidikan dan keterampilan akan mendorong kemajuaan setiap usaha dan meningkatkan pendapatan.

\section{Kesimpulan}

Pada analisis multivariat menunjukkan bahwa variabel yang paling dominan berpengaruh terhadap pemanfaatan pelayanan posyandu lansia adalah sikap lansia. Lansia yang bersikap negatif lebih beresiko 6 kali untuk tidak memanfaatkan pelayanan posyandu lansia dibandingkan dengan lansia yang bersikap positif setelah dikontrol oleh variabel sikap, jarak tempuh, dukungan keluarga, motivasi kader dan pendidikan.

\section{Saran}

Hasil penelitian menunjukkan bahwa pemanfaatan pelayanan posyandu lansia masih sangan rendah, diharapkan dinas kesehatan kota sebagai instansi yang terkait maka perlu dilakukan upaya untuk meningkatkan pemanfaatan pelayanan posyandu lansia melalui promosi dan penyuluhan tentang pemanfaatan posyandu lansia, serta meningkatkan kualitas pelayanan di posyandu sehingga para lansia termotivasi untuk mengunjungi posyandu lansia dan pelaksanaan posyandu diharapkan dilaksanakan secara rutin setiap bulannya. Tempat pelaksanaan posyandu lansia diadakan di pemukiman masyarakat agar mudah terjangkau oleh lansia setiap diadakan kegiatan posyandu. Puskesmas sebagi tempat pelayanan kesehatan dasar yang berhadapan langsung dengan masyarakat, agar memfasilitasi dan mendukung semua kegiatan yang diadakan sehingga posyandu lansia dapat berjalan sesuai yang diharapkan.

\section{Daftar Pustaka}

Anderson, T Elizabeth, 2007 Keperawatan Komunitas Teori dan Praktik. Penerbit Buku Kedokteran

Biro Pusat Statistik, 2007.www.Menegpp. Go.id/aplikasidata/index.php?option.com. diakses 2 maret 2011

Dep Kes RI , 2009. Undang-undang Kesehatan No 36. Pasal $138 \quad$ http://dinkessulsel.go.id/new/images/Berita4/1.uu36-09kesehatan.pdf. diases juli tanggal 3 tahun 2011

Depkes RI, 2005. Pedoman Pembinaan Kesehatan Usia Lanjut Bagi Petugas Kesehatan. Jakarta: Bina Kesehatan Masyarakat Departemen Kesehatan

Dinkes Provinsi Riau 2010. Profil Kesehatan Provinsi Riau: Dinas Kesehatan Provinsi Riau

Ediyana, 2005. Faktor-Faktor yang Berhubungan Dengan Status. Jakarta : Fakultas Kesehatan Masyarakat Universitas Indonesia

Hardywinoto, Setiabudhi 2007. Panduaan Gerotologi. Jakarta : Pustaka Utama

Harianto, 2004 Peningkatan Mutu Pelayanan Kesehatan Jakarta Pustaka Rupa

Henniwati, 2008. Faktor-Faktor yang Mempengaruhi Pemanfaatan Pelayanaan Posyandu Lanjut Usia Di Wilayah Kerja Puskesmas Kabupaten Aceh Timur. Tesis Pascasarjana Universitas Sumatra Utara

Martono, Hadi dan Kris Pranarka, 2009. Geriatri Ilmu Kesehatan Usia Lanjut. Falkutas Kedokteran : Jakarta

Notoatmodjo, S. 2003. Buku Ajar Kesehatan Masyarakat. Jakarta. EGC

Notoatmodjo, S. 2005. Promosi Kesehatan. Jakarta: Rineka Cipta 
Nugroho, 2006. Keperawatan Gerontik.Jakarta : EGC

Nurhayati, 2007. Pengaruh Karateristik Individu Terhadap Pemanfaatan Posyandu dan Hubungannya dengan Kemandiriaan Usia Lanjut di Puskesmas Hevetia Medan: Tesis Program Administrasi dan Kebijakan Kesehatan Sekolah Pascasarjana Sumatra Utara
Purnomo, 2010. Hubungan antaraTingkat Pengetahuan Tentang Penyakit Reumatik Dengan Sikap Lansia Dalam Mengatasi Kekambuhan Penyakit Reumatik Di posyandu Lasia Kelurahan Karangsem Kecamatan Laweyan Koto Surakarta. Skripsi Fakultas Ilmu Kesehatan Universitas Surakarta. 